\title{
Climate change politics and the role of China: a window of opportunity to gain soft power?
}

Rauchfleisch, Adrian ; Schäfer, Mike S

\begin{abstract}
In China today, the idea of "soft power" has become important in various realms of society. We analyze the nexus between climate change and soft power with specific emphasis on China. First, we will discuss the concept of soft power, its role in the Chinese context, and the reasons why China has had difficulties to gain soft power up to now. Second, we lay out how international climate change politics are an important arena in which soft power can be won and how the issue has gained importance in China. In a third step, we discuss how the current political environment, in which the US government has changed its stance on climate change and international climate politics, impacts China. Our thesis is that the current political situation represents a "window of opportunity" for China to expand its soft power substantially both in degree and scope. In line with this thesis, so far, China has reacted swiftly after the election of US president Donald Trump and aims to present itself as the future climate leader.
\end{abstract}

DOI: https://doi.org/10.1007/s40636-018-0114-9

Posted at the Zurich Open Repository and Archive, University of Zurich

ZORA URL: https://doi.org/10.5167/uzh-159683

Journal Article

Accepted Version

Originally published at:

Rauchfleisch, Adrian; Schäfer, Mike S (2018). Climate change politics and the role of China: a window of opportunity to gain soft power? International Communication of Chinese Culture, 5(1-2):39-59.

DOI: https://doi.org/10.1007/s40636-018-0114-9 


\title{
Climate change Politics and the Role of China: A Window of Opportunity to Gain Soft Power?
}

\begin{abstract}
In China today, the idea of ,soft power" has become important in various realms of society. We analyze the nexus between climate change and soft power with specific emphasis on China. First, we will discuss the concept of soft power, its role in the Chinese context, and the reasons why China had difficulties to gain soft power up to now. Second, we lay out how international climate change politics are an important arena in which soft power can be won and how the issue has gained importance in China. In a third step, we discuss if the current political environment, in which the US government has changed its stance on climate change and international climate politics, provides a window of opportunity for China to assume a new role as a global leader in the fight against climate change and, thus, gain soft power. Our thesis is that the current political situation represents a "window of opportunity" for China to expand its soft power substantially both in degree and scope. China has reacted swiftly after the election of the US president Trump and presents itself as the future climate leader. Still, this move might be not enough to outdo the US overall, but it is the first step for China towards real soft power with global influence.
\end{abstract}

Keywords

China - Soft Power - Climate Change - International Relations - Communication

With regards to climate change politics, the world has turned upside down in the last months. On December 12, 2015, the "Paris Agreement" was formulated at the 21st "Conference of the Parties" (COP21) to the United Nations Framework Convention on Climate Change (UNFCCC), in which the 195 participating countries agreed on a roadmap to reduce greenhouse gas emissions to replace the "Kyoto Protocol" (CarbonBrief, 2015). 18 months later, however, in June 2017, newly elected president Donald Trump announced the US would pull out of the agreement (The Guardian, 2016), drawing criticism from many heads of state, political parties and stakeholders around the globe (World Economic Forum, 2017). At around the same time, Trump selected Scott Pruitt - a pronounced climate change denialist with connections to the fossil fuel industry - to lead the U.S. Environmental Protection Agency (EPA) (Davenport \& Lipton, 2016), proposed significant funding cuts for climate change research (Grennfieldboyce, 2017) and greenlighted an oil pipeline project previously stopped because of environmental concerns (Holland \& Volcovici, 2017). With these decisions, the Trump administration reversed course from its predecessor and from a position towards climate protection that had found widespread international consensus at the 2015 Paris summit.

Another international player positioned itself notably different at the same time: China. When Chinese President Xi Jinping has visited other countries recently, environmental issues and climate protection were often on the agenda (e.g., Switzerland; The Federal Council, 2017), and according to Vice Foreign Minister Liu Zhenmin, the country will continue its fight against climate change "whatever the circumstances" (Shankleman, 2016). After Donald Trump's election, Chinese officials even reminded him that global warming is an existing, serious problem that needs to be dealt with in international cooperation (Phillips, 2016). 
China's more active role in climate change politics, and its increased activity and different approach to international relations in general, is in line with the country's goal to increase its "soft power". The concept of soft power was introduced by Joseph Nye towards the end of the cold war (Nye, 1990a), referring to "the ability to affect others to obtain the outcomes one wants through attraction rather than coercion or payment" (Nye, 2008, p. 94). Originally, the US during the cold war was the prime example of a country with relatively extensive soft power. Democratic values and the cultural industry of Hollywood, Japan or South Korea are seen as major resources of soft power with global appeal (Nye, 2002; Otmazgin, 2007; Ryoo, 2009). Authoritarian countries such as China traditionally lacked these resources (Wang, 2008). However, in 2005 Nye (2005a) pointed out the substantial gains China had made regarding soft power. Still, in the current debate whether China is successful with its public diplomacy efforts, many doubt that China has successfully gained soft power (e.g., Blanchard \& Lu, 2012; Creemers, 2015; Heng, 2010; Paradise, 2009).

We analyze the nexus between climate change and soft power with specific emphasis on China. First, we will discuss the concept of soft power, its role in the Chinese context, and the reasons why China had difficulties to gain soft power up to now. Second, we lay out how international climate change politics are an important arena in which soft power can be won and how the issue has gained importance in China. In a third step, we discuss if the current political environment, in which the US government has changed its stance on climate change and international climate politics, provides a window of opportunity for China to assume a new role as a global leader in the fight against climate change and, thus, gain soft power.

\section{Soft Power and the Case of China The Concept of "Soft Power"}

International politics is the prime example of Realpolitik: Countries are actors who have strong preferences, and the primary goal of every country's foreign policy is to act according to those interests. Foreign policies always affect other countries. Especially rising powers such as China's have to make their rise palatable to the world and win support for their policies (Hooghe, 2010). There is a broad range of options available for a country to reach its goal in international politics. They can be best divided into the general categories hard and soft power that are part of a continuous power spectrum (Nye, 2005b).

The traditional tools of international politics, "sticks and carrots", are aptly described as "hard power": Countries and international organizations often try to coerce other nations or international organizations to behave some way rather than another, either using force or money (Nye, 2008). There exist many prominent examples in world history where countries used mostly hard power to achieve their goals in international politics. Spain, for instance, in the sixteenth century mainly relied on mercenary armies and trade to become a leading state in world politics (Nye, 1990a). Nowadays, relying only on hard power is difficult. Ney (1990b) argues that "the direct use of force for economic gain is generally too costly and dangerous for modern great powers. Even short of aggression, the translation of economic into military power resources may be very costly" (p.157).

Hard power never was, and still is not the only force of international politics: In the early 1990s, political scientist Joseph Nye coined the term "soft power" (Nye, 1990a, 2008) to emphasize that countries and, to a lesser degree, international organizations sometimes manage to persuade other international actors not by means of hard power, but by a form of virtue signalling. According to Nye, soft power is the ability „to affect others to obtain the outcomes one wants through attraction rather than coercion or payment" (2008, p. 94). Sometimes, countries want to cooperate with and follow another country not because they are forced to, but because some actions, practices, and characteristics of that country are appealing. Nye (Nye, 1990b) describes this in its ideal form as co-optive 
power, which "is the ability of a country to structure a situation so that other countries develop preferences or define their interests in ways consistent with its own" (p.168).

While the concept received a lot of academic attention, the explicit distinction between "hard" and "soft power" has been discussed at length. Both hard power and soft power "are aspects of the ability to achieve one's purposes by controlling the behaviour of others" (Nye, 1990a, p. 181) and form a continuum of power. Some resources such as payments can be, depending on the context, either be interpreted as "hard" or "soft power". Heng (2010) and others (e.g., Blanchard \& Lu, 2012; Nye, 2005b) have criticized the inconsistent use of the concept by some authors and policy experts. We believe it is vital to distinguish hard power from soft power, e.g., when talking about economic interventions that can often be best described as payments which are according to Nye (1990a) part of hard power. However, it would be analytically short-sighted to describe payments always as hard power. Blanchard and $\mathrm{Lu}$ (2012) propose to consider "nonconditional payments that involve considerable generosity or sacrifice" (p.568) as soft power. Overall, grasping and measuring soft power and its dimensions has proven as challenging. ${ }^{1}$ Nye (2008) himself identified three primary resources on which the soft power of a country rests: "its culture (in places where it is attractive to others), its political values (when it lives up to them at home and abroad), and its foreign policies (when they are seen as legitimate and having moral authority)" (p. 96). Soft power, in contrast to hard power, is intangible. The "attractiveness of ...[its] components is partly in the eye of the beholder" (Blanchard \& Lu, 2012, p. 569) and "there is always danger of bias in evaluating cultural sources of power" (Nye, 1990b). While the possible source of "soft power" is often clear, defining the target, a country or international organization, of "soft power" is difficult. With hard power the target is clear because the resources of hard power are tangible and traceable.

The measurements employed to operationalize these dimensions differ. To measure the cultural facet of soft power, for example, scholars have turned towards the number of people in other countries studying the respective country's culture or language (Ding \& Saunders, 2006), towards the size of audiences for its media (Blanchard \& Lu, 2012) or the success of cultural institutions such as the Chinese "Confucius Institutes" in other countries (Gill \& Huang, 2006). Soft power in terms of political values has been interpreted, for example, as the existence of a market-based economy (Gill \& Huang, 2006) and, most importantly, as a country's adherence to human rights (Ding, 2012; cf. Thomas, 2001). And regarding foreign policy, soft power was interpreted as the membership in international organizations (Gill \& Huang, 2006), the involvement in international disputes (Gill \& Huang, 2006) or the participation in international peacekeeping missions (Wu \& Taylor, 2011). But while the measurements differ, and are partly debated in the scholarly literature, the general dimensions of soft power - culture, political values and foreign politics - were taken up by many scholars in the field (for overviews see Blanchard \& Lu, 2012; Gill \& Huang, 2006).

Another important facet is that soft power lies "in the eye of the beholder" (Blanchard \& Lu 2012, p. 569). Eventually, the soft power of a country can only be judged by its appeal to others. Therefore, it does not suffice to focus on a country's resources. The perceptual effect of these resources has to be taken into account, and only if they lead to attraction we can speak of soft power. Therefore it is important also to analyse how the targets of soft power receive and interpret values and policies and whether these resources are appealing to them.

\footnotetext{
${ }^{1}$ In addition, authoritarian countries such as Russia or China advance their own, potentially politically motivated interpretations of the concept in ways that conform to their foreign and domestic policy interests Edney (2012).
} 


\section{The Rising Importance of the Concept of "Soft Power" in China}

In China today, the idea of ,soft power" has become important in various realms of society. First, it arrived in Chinese politics about ten years ago. In 2007, a Chinese government official mentioned soft power for the first time publicly (Wang, 2008). During the plenary session of the 18th National Congress of the Communist Party of China in 2012, China's President Xi Jinping mentioned the goal to ,increase the national cultural soft power“ (提高国家文化软实力 tigao guojia wenhua ruan shili) (Xi, 2012)a phrase he has used as early as 2008 in some of his speeches long before his presidency (Xi, 2008).

Second, the concept of soft power has also become popular amongst Chinese academics (Wang, 2008). Chinese scholars started to debate the concept after 2000 (Mingjiang, 2008; Wang \& Lu, 2008). The popularity of the concept can be best illustrated with data from the China National Knowledge Infrastructure database (CNKI) (Mingjiang, 2008; Wang \& Lu, 2008). ${ }^{2}$ When searching for academic articles in the database mentioning the Chinese translation of soft power that is now most commonly used (软实力 ruan shili), a clear trend is visible. Interest in soft power first emerged in 2001, with the strongest growth between 2007 and 2008 when the concept for the first time entered the political arena in China (Wang, 2008). Since 2008, the annual number of Chinese scholarly articles on soft power has almost doubled and reached a plateau of at least 3.000 articles per year in 2012 (see Fig. 1).

A similar trend emerges, third, when looking at Chinese mass media. We searched for the term soft power (软实力 ruan shili) in the China Core Newspapers Full-text Database and analyzed how many articles were published in Chinese newspapers each year (see Fig. 2). Similarly to the trend among Chinese academics, the term soft power started to appear in the media in the early 2000s, and the number increased until 2011 before plateauing around 750 articles a year. Soft and hard power have also been included as terms in China's official lexicon in 2009 (Qin \& Tatlow, 2014).

This comparative analysis of politics, academia and media coverage shows: The concept of soft power is not just an intellectual fad in Chinese society that will vanish soon. Furthermore, it is probably one of the few concepts with roots in academia that has a substantial impact on politics and society as these examples illustrate.

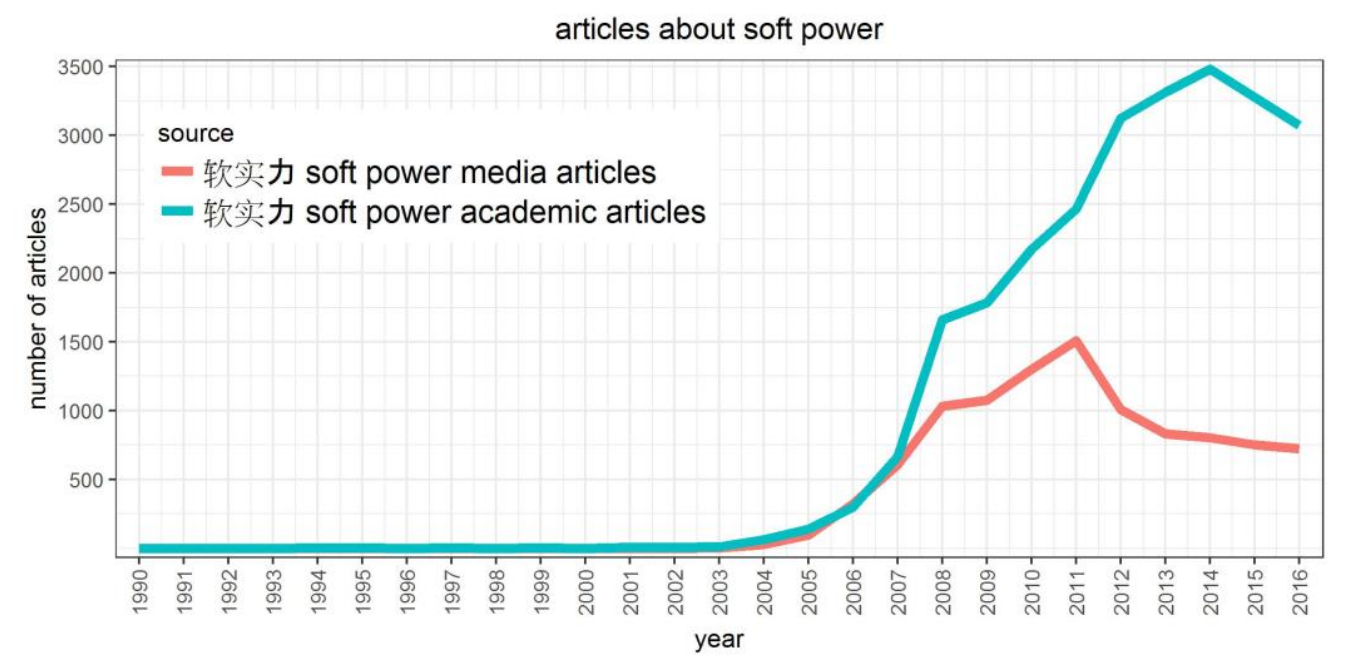

Fig. 1: Number of Chinese articles about soft power. Data from CNKI database covering articles in academic publications and media articles.

\footnotetext{
${ }^{2}$ Both articles also analysed the popularity of the concept with data from the CNKI database. We include an updated version of this analysis in our article.
} 


\section{China's Difficulties in Acquiring Soft power}

Soft power has become an important and widely discussed concept in China, and Chinese politics has promoted improvements in soft power to a critical political goal. While all countries are interested in soft power, authoritarian countries such as China have often failed to build up soft power, despite significant efforts to do so. In the literature, it is still debated how much soft power China gained exactly, even though academics such as Nye (2005a) acknowledge the country's efforts. Ding (2010), for example, optimistically concludes that China has gained a substantial amount of soft power through foreign aid programs or the 2008 Beijing Olympic Games (see also Hunter, 2009). The Confucius Institutes as cultural initiatives are also often mentioned as a successful part of China's soft power strategy (Hartig, 2012; Heng, 2010; Paradise, 2009; Servaes, 2015). But even though these examples might help China gain soft power, their effectiveness has been questioned numerous times. In one of the most recent soft power rankings, China still only holds position 25 out of 30, whereas the US claimed third place and France was first (McClory, 2017). ${ }^{3}$ We will briefly discuss Chinas ability to generate soft power with the three primary resources described by Ney.

\section{Culture}

First of all, the influence of state-sponsored cultural institutions such as the Chinese "Confucius Institute" has been described as limited (Paradise, 2009), because "cultural soft power can be undercut by policies that are seen as illegitimate" (Nye, 2008, p. 96). In his analysis of China's cultural programs, Creemers (2015) concluded that they "are rarely successful even in their home markets" (p. 306). This is an important point because the Chinese discourse of the concept of soft power focuses to a large extent on the domestic context (Mingjiang, 2008; Wang \& Lu, 2008). Especially when the concept was first popularized in China, it was often understood as top-down communication resembling (domestic) public affairs activity and not (international) public diplomacy (Wang, 2008) and ignoring the ambiguous nature of soft power resources (Blanchard $\& \mathrm{Lu}, 2012)$. Furthermore, the Chinese understanding of soft power emphasizes traditional culture, whereas Nye mainly highlights contemporary popular culture as the basis for soft power (Wang \& Lu, 2008). Wang (2008) goes even further and describes Chinese culture as a "considerable obstacle to effective Chinese diplomacy" (p.262). This is in stark contrast with the Chinese approach with a strong focus on culture. In general, the culture-based public diplomacy approach is in line with the misconception of the Chinese "that historical significance [would] automatically convert into contemporary influence" (Wang, 2008, p. 261).

With regards to contemporary culture, however, the Chinese lack influence and appeal. Buchholz (2013) for example shows that China only ranks in the global "semi-periphery" when it comes to the worldwide "Distribution of Transnational Art Institutions" (p. 75) as well as "art auction houses" (p. 94), far behind the US, the UK, Germany and other developed countries. Also in terms of global cultural content production, including content such as movies and copyrights, China was in the past far behind nations such as the US and Japan and on the same level as South Korea which is a far smaller country (Otmazgin, 2007).

\section{Political Values}

China's hosting of the 2008 Beijing Olympic Games was seen as a domestic success (Manzenreiter, 2010). However, the games "also invited new international scrutiny and

\footnotetext{
${ }^{3}$ Such rankings have to be taken with a grain of salt because they reduce soft power as a nontangible element of international relations to a few measurable indicators. Also the weighting of the indicators (e.g. cultural aspects have a lower weight than social media use of head of states) shows that the creators of the ranking are mostly interested "public relation" parts of soft power.
} 
demands for openness which the emerging power will have to contend with" (Cornelissen, 2010, p. 3017). In the international press, the hosting of the Olympic Games also elicited counter-narratives highlighting China's human rights violations (Manzenreiter, 2010).

This is symptomatic: Major events like the Olympic Games can be a double-edged sword for any country, and particularly for less developed ones. On the one hand, emerging economies like China have the opportunity to present themselves as modern states with these events. On the contrary, they create an opportunity for marginalized groups such as Tibetans to create public protests that are in some cases widely covered in the press. One such example was in March 2008 before the Olympic Games in Beijing when Tibetan organizations were publicly protesting during the Olympic torch rally in Greece. The Olympic Games facilitated a public debate about human rights issues in China (Brownell, 2012). The protests and the Tibetan unrest in April 2008 lead to an increased foreign interest in the human rights situation in China (see Fig. 4 with the relative highest Google search volume for human rights in China in April 2008). There are even indicators that the attitude of US citizens towards China worsened during the games as Gries, Crowson, and Sandel (2010) showed with survey data. Pundits concluded after the Games that "[t]he world is increasingly doubtful that Beijing will reform politically and become a responsible global actor" (Economy \& Segal, 2008, p. 56). Thus, the Games might have been a domestic success (Blanchard \& Lu, 2012), but whether they increased China's soft power is doubtful. In general, mega-events such as the Olympic Games or the world EXPO signal "something different in every context and with every different target" (Nordin, 2012, p. 594). While China shows some improvement with the social indicators and, in general, economic development, China still fails "in promoting and defending human rights values, particularly in civil and political rights" (Ding, 2012, p. 661).

\section{Policies}

China's expansion of national interest, especially in the South China Sea ${ }^{4}$, has been critically viewed by neighboring countries and the international community (Yahuda, 2013). Still, amongst the many Chinese policies that might have helped to gain soft power, disaster relief, and humanitarian aid have frequently been mentioned as a resource of Chinese soft power (e.g., Blanchard \& Lu, 2012; Gill \& Huang, 2006). China started to increase its foreign aid in the South Pacific (Lanteigne, 2012). The policy dimension and more specifically foreign aid should not be underestimated as a major resource contributing to soft power (Ding, 2012). However, the efforts in recent years might not be enough to build soft power. Even though China has already become the $4^{\text {th }}$ largest contributor in foreign aid help globally, their commitment can be critically assessed (Hu, Zhang, \& Gao, 2017). China's foreign aid still does not match its economic power and industrial nations such as the US, Germany or Japan still provide more foreign aid than China even though their GDP is lower than China's (Hu et al., 2017).

\section{Climate Change Politics and Chinese Soft Power}

As described above, scholarship so far shows that China has had difficulty to gain soft power based on any of the three resources described by Nye. Out of culture, political values and foreign policies, the country's best chance is to be successful with foreign policies. After all, culture and values cannot be created or changed in the short run, whereas policies are fully in state control and can be adapted short term. Furthermore, culture and values can always send ambiguous messages and can be differently interpreted by the targeted countries depending on the context. International climate change politics are particularly interesting in this respect. The withdrawal of the US

\footnotetext{
${ }^{4}$ The name „South China Sea“ is highly contested. Each country in the area has its own name for the sea.
} 
administration from the UNFCCC process and the Paris Agreement can be interpreted as a window of opportunity for China to gain soft power through climate change policies.

\section{Climate change as an International Challenge}

Climate change is a global problem - potentially the "moral challenge of our generation", as United Nations' General Secretary Ban Ki Moon put it (Guardian, 2007) - caused by activities of people from countries around the world (albeit to different degrees). Greenhouse gas emissions produced by human activity contribute to increasing temperatures around the world and corresponding changes in precipitation, wind speeds, droughts, rainy periods, etc. that influence the natural and social world (Dryzek, Norgaard, \& Schlosberg, 2011; IPCC, 2014). Accordingly, political responses and solutions are also sought on a global level, mainly in the UNFCCC process aiming to reduce greenhouse gas emissions and adapt to already occurring climate change.

Finding political solutions on the international level, however, is challenging (Keohane \& Victor, 2011). In the UN process, consensual decisions are needed (Brunnengräber, 2012), and therefore, decision-making can become more difficult, take more time or are watered down to the smallest common denominators (Gupta, 2010). Finding common ground is difficult because climate change poses a global "drama of the commons" (Dietz, Dolšak, Ostrom, \& Stern, 2010): “Actors profit individually from greenhouse gasproducing activities, whereas they would gain only a fraction of the benefits from unilateral mitigation efforts causing abatement costs" (Schmidt, Ivanova, \& Schäfer, 2013, p. 1233), and "their sacrifice may be futile if other actors do not exhibit similar restraint" (Harrison \& Sundstrom, 2007, p. 1).

In the past industrialized as well as developing countries both were confronted with the trade-off between economic growth and reduction of carbon dioxide emissions.

Especially countries like China with strong economic growth and high emission of carbon dioxide put the responsibility to reduce emission on Western countries because their behavior in the past lead to the climate change we are experiencing today (cf. Guo, 2010; $\mathrm{Xu}, 2010)$. In order to convince developing nations to reduce their emission of greenhouse gases in general, industrialized countries had to start with a commitment and take the leadership role. When the US announced to leave the Kyoto treaty in 2001, the European Union decided to ratify the treaty and take the climate change leadership (Schreurs \& Tiberghien, 2007). The Obama administration later took over the leadership role, together with European leaders from France and Germany, and helped come to an agreement in 2015 at COP2 1 in Paris. In 2016 after Trump was elected as the new president in the US the Chinese started to verbally take over the leadership role in the fight against climate change (Hilton, 2016).

The 2001 and 2007 examples show that countries can take over leadership roles once they are vacated. In the case of the EU in 2001, norms such as social equality is mainly the result of "the actions and commitments of a group of pioneering states and the leadership roles played by the European Parliament (EP) and especially, the European Commission" (Schreurs \& Tiberghien, 2007, p. 22). Of course, such policies also followed public opinion in the EU where the majority of people sees the protection of the environment as a priority (Schreurs \& Tiberghien, 2007; Spence, Poortinga, Butler, \& Pidgeon, 2011).

\section{Climate Change and Climate Change Politics in China}

In some regards, China is already positioned to become a leader in climate change politics. First, climate change has become an important issue in China recently. Partly, this is due to the country being affected by the problem. Primary effects of climate change such as extreme weather events, rising sea levels, biodiversity loss, or health risks are expected to increase in China, from a rating of "low" vulnerability according to the 
"Climate Vulnerability Monitor" (DARA, Climate Vulnerable Forum, 2012) in 2010 to a "moderate" rating in 2030. China's vulnerability to secondary, socioeconomic effects of climate change mitigation and adaptation - which would involve major changes in energy production and consumption - is even higher. It was rated as "severe" by the "Climate Vulnerability Monitor" in 2010 and expected to be "high" in 2030.

As a result, second, climate change has become a major issue for the Chinese government as well as for the Chinese public. In a recent survey by the Pew Research Center, a third of Chinese respondents see climate change as a major threat to China (73\% see climate change at least as a minor threat) (Pew Research Center, 2016a, p. 21). In turn, the degree of climate change scepticism - doubting the existence, human-made causes and/or serious effects of climate change - is much less pronounced in China compared to other, most notably Anglo-Americans countries (e.g., Painter, 2011). Additionally, environmental NGOs have sprung up in China dealing with climate change as a core issue (e.g., Segerberg, 2017). Also, media attention for climate change has strongly risen in China since 2007, to an above-average amount in global comparison (Schmidt et al., 2013). We extended the analysis of Schmidt et al. (2013) and used data from the China Core Newspapers Full-text Database to analyze how many articles were published in Chinese newspapers each year. For the last decade, Fig. 1 shows a significant amount of media coverage with temporary peaks in 2007 and 2009. Both in 2007 in Bali and 2009 in Copenhagen climate summits of the United Nations took place. Both events were amongst the ten most important topics in foreign news in China in the respective year $(\mathrm{Xu}, 2010)$. The amount of media coverage fell in the following years but again peaked in 2015 with COP21 in Paris that resulted in an agreement where both the US and China joined. (cf. Daly et al., 2017)

Apart from perceiving the issue of climate change as important, the Chinese position towards it also changed its focus over the past years. This is visible in the political positioning as well as in the mass media coverage in China, which shifted from a passive and instrumental towards a proactive, environmental frame when covering climate change. In the mid-2000s, Chinese media coverage of the issue focused strongly on the division between "[t]he rich, the poor and global politics" (Xu, 2010, p. 138). China was presented rather positively, in "heroic frame, a 'self-celebratory frame" (Xu, 2010, p. 139), and developing countries were interpreted as not needing to reduce greenhouse gas emissions. This perspective held true until 2009 when the Copenhagen summit took place. During the summit, Chinese TV largely was "situating responsibility outside [Chinese] boundaries" (Liang, Tsai, Mattis, Konieczna, \& Dunwoody, 2014, p. 267): It claimed that industrialized countries were historically responsible for climate change and, therefore, also in charge of solving the problem. Fittingly, coverage strongly featured rifts between these industrialized nations, e.g., discussions between the US and the European Union about their respective responsibilities (cf. Xu, 2010).

Beginning in 2009, however, China was increasingly presented by domestic media as a more active player and even a leader in international climate politics, as a country which "move[d] together with developing countries" (Xu, 2010, p. 139). Accordingly, the previously passive description of divides between the US and the EU gave way to China being described as an adversary of, mostly, the US. "The "EU vs. US division" frame was replaced by several divisions including a "China vs. US division", a "China vs. EU division" and a "China, India, Brazil, South Africa vs. others division". (Xu, 2010, p. 140). And the "Chinese government accepted this responsibility [as a leader of other developed countries] and sought to negotiate a deal with the developed nations that would not put an unacceptable burden on China and other developing nations" (Liang et al., 2014, p. 167; cf. Xu, 2010). Potentially the Chinese engagement in favour of developing 
countries may have led to a first increase in the countries soft power. It was the first time China presented itself as a potential climate change leader.

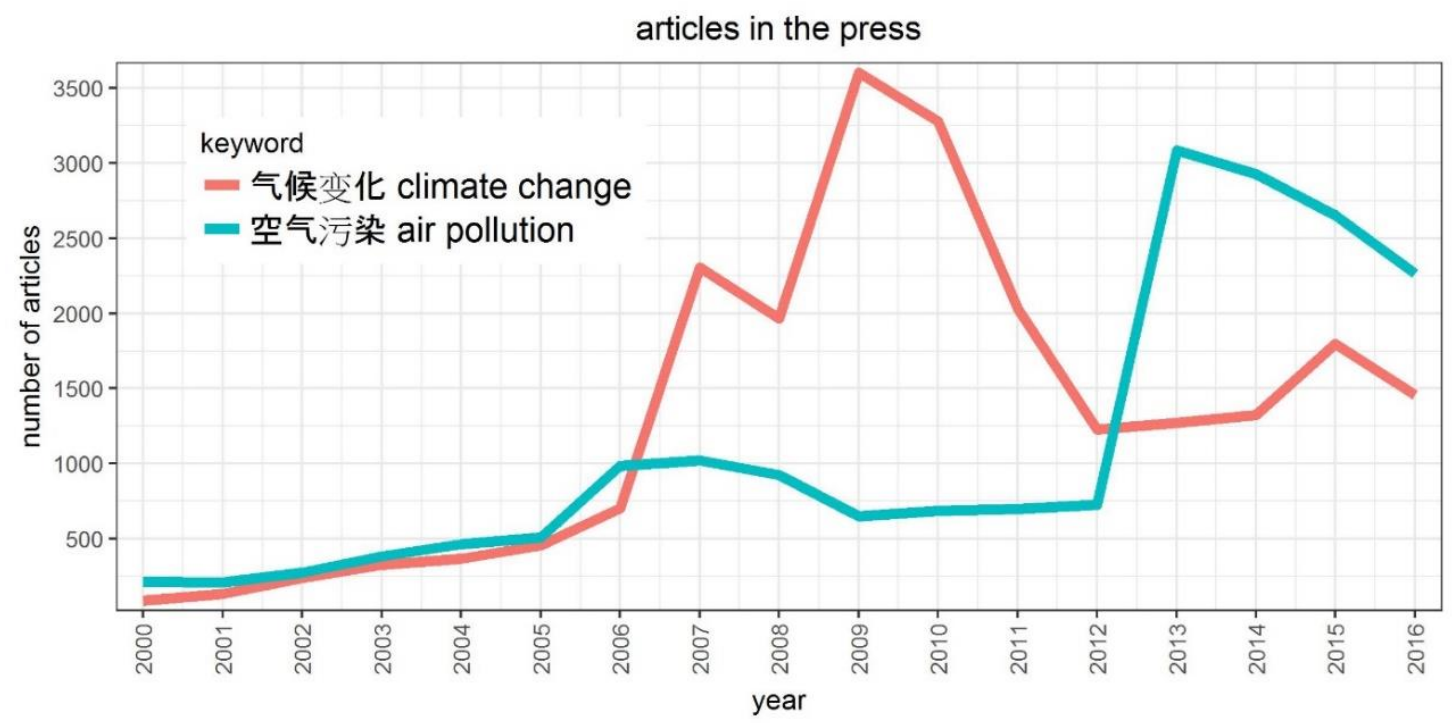

Fig. 2: Number of Chinese articles in the press covering climate change and air pollution. Data from CNKI database.

Third, Chinese politicians and media did not only interpret their position differently themselves, but the country was also increasingly interpreted as a relevant player in climate change politics to whom a portion of political responsibility was attributed by others (Konieczny, 2014; e.g., Schmidt \& Schäfer, 2015). Largely based on the country's size and its national greenhouse gas emissions, it was seen as legitimately "representing the perspectives of developing nations (e.g., Group of 77, a coalition of developing nations at Copenhagen Summit)" and in doing so, as the natural adversary to the "United States ... as the leading developed nation" (Liang et al., 2014, p. 256). Connected to this position was a "growing voice in the world media and politics, which asked China to take the same responsibility in cutting emissions as the developed countries" (Xu, 2010,

p. 131; see also Broadbent et al., 2016; Johannessen, 2015), a position that was particularly pronounced in the conservative US media and among US politicians (Schmidt \& Schäfer 2015).

\section{China's window of opportunity to gain soft power}

Our thesis is that the current political situation represents a "window of opportunity" for China to expand its soft power substantially both in degree and scope. As we have shown, furthering the country's soft power in international relations has been a major impetus of Chinese foreign politics in the past decade, and extensive attempts to achieve this were being made. Their effect has been limited, however, due to a number of difficulties. Most importantly, soft power can rest on the three pillars of cultural appeal, attractive political values and positively perceived foreign politics - and in the cultural and value dimension China has had difficulties boosting its soft power. Apart from being unable to boost its degree of soft power substantially, Chinese efforts were also limited to a small number of countries so far - mostly the developing countries for whom China acted as a leader in international climate change politics.

With the changed position of the US towards climate change under the Trump administration, however, a new opportunity presents itself to China to take over a 
stronger, more expanded leadership role in the international political efforts to mitigate climate change. For a number of reasons, it is conceivable that the Chinese government could seize this opportunity. The issue of climate change has been recognized by Chinese politics (Blas \& Shankleman, 2017) as well as by the country's public and its media as relevant and important (Pew Research Center, 2016a; see also Fig. 2). The Chinese position in international climate change negotiations has changed from being passive and reactive towards being more proactive and constructive (see COP21 in 2015 and the bilateral agreement with the state California in 2017 after Trump took over the office). And the external perception of the country has increasingly highlighted the amount of its current greenhouse gas emissions and, as a result, attributed responsibility for climate change politics to China, among other countries (e.g. Liang et al., 2014). Assuming a leadership role in international climate change politics, therefore, gives China the opportunity to expand its soft power, especially towards industrialized nations (e.g., the EU) in which climate change is seen as the major challenge of the $21^{\text {st }}$ century (Schreurs \& Tiberghien, 2007). Still, some obstacles might prevent the Chinese to implement the policies necessary and, as a result, to gain soft power by taking on an international leadership role in climate politics.

First, China has to tend to the most pressing environmental issues domestically before being able to expand in climate change politics. Air pollution and water pollution as the more tangible problem in contrast to the more abstract climate change are amongst the major concerns of Chinese people (Pew Research Center, 2016a, p. 7). This can be illustrated with data from the Chinese search engine 360. Our analysis shows that the problem of air pollution and water pollution by far exceeds the interest in climate change at any given time (see Fig. 3). In January 2017, interest in water pollution peaked because the government fined a chemical plant for environmental damage (Leng, 2017). In contrast to the two domestic pollution problems, interest in climate change is relatively small.

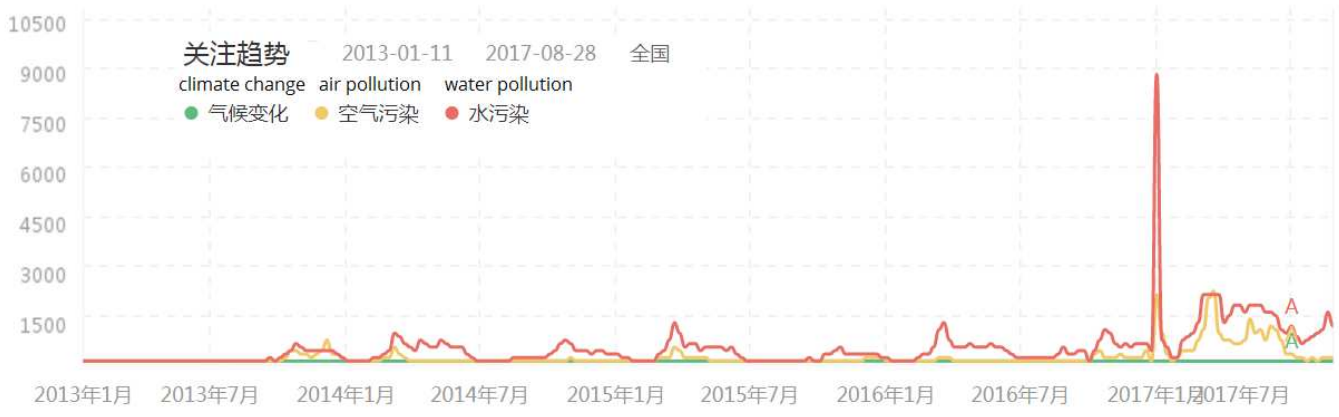

Fig. 3: 360-trend relative daily search volume between January 2011 and August 2017.

Still, when directly asked, Chinese citizens describe climate change as a problem. In a recent survey by the Pew Research Center, a third of Chinese respondents see climate change as a major threat to China (73\% see climate change at least as a minor threat) (Pew Research Center, 2016a, p. 21). To fight climate change, China must decrease its carbon dioxide emission - a move that is likely to curb China's economic growth in the short run. However, the abovementioned Pew survey showed that $50 \%$ of respondents believe "We should reduce air pollution even if it means slower economic growth" in contrast to only $24 \%$ of respondents agreeing that "Air pollution is the price we have to pay for continued economic growth" (Pew Research Center, 2016a, p. 5). Even from an economic point of view "it is smart planning to set long-term emission-reduction targets ... and give ... companies, entrepreneurs, and investors certainty so they can

\footnotetext{
${ }^{5}$ The increased environmental awareness of the Chinese public is perfectly illustrated by the documentary "Under the Dome", produced by former journalist Chai Jing. When she released her documentary in Spring 2015 on the Chinese Internet, the video went viral with over 100 million views in the first 24 hours Yang (2015).
} 
invest and manufacture the emission-reducing technologies that we can use domestically and export to the rest of the world" (Obama, 2017, p. 3). This is not a quotation from a Chinese official, but those are the words of the outgoing U.S. President Barack Obama in the journal "Science". In that paper, Barack Obama is talking about the economic opportunities for the U.S. that climate change can present if necessary action is taken. His argument: growth and carbon dioxide emission can be decoupled.

Second, China needs to successfully manage competing issues in order to gain international credibility for climate change politics and, thus, potentially be able to expand the scope of its soft power. Even though air pollution is mainly a domestic problem, China has to solve this issue also with regards to its perception from other countries. Only if the international image of China is congruent with the climate change policies, China gains soft power - and a major challenge for China is its negative image with regards to environmental issues in the Western press. Guo (2010), for example, analyzed the reporting about China and climate change in the New York Times. In 2009 $40 \%$ of the articles presented China's role in connection with climate change in a negative way. He concludes that China needs to improve its international image and present the country more as “ecological China" (生态中国 shengtai zhongguo). Our analysis of the Google search data shows that air pollution is a major concern internationally and even dwarfs the attention China receives from abroad for its climate change policies (see Fig. 4).

Even if China can solve its domestic air pollution problem and achieve its climate change goals, the violation of human rights might still prevent China from gaining soft power. As long as there is no positive development in the area of human rights, China is unlikely to gain enough soft power to influence Western countries meaningfully. Our Google search data shows that human rights in China still receive a lot of international attention (see Fig. 4). With regards to soft power, Ding (2012) describes human rights as the potential Achilles' Heel of Chinese soft power. For instance, by international standards, China is ranked on one of the last position in the "Freedom in the World" ranking (Freedom House, 2017) and has one of the lowest scores in the world in the civil liberty dimension of the Democracy Index (The Economist Intelligence Unit, 2017). Furthermore, survey data shows, for example, that $95 \%$ of Germans see the promotion of human rights as an important foreign policy goal (Pew Research Center, 2016b). The same holds true for Spain (90\%), Netherlands (88\%), Sweden (92\%), and the UK (84\%). Furthermore, $70 \%$ of Europeans see "China's emergence as world power" (Pew Research Center, 2016b, p. 14) at least as a minor threat. Still, the same survey data shows, that climate change is seen by $66 \%$ of Europeans as a major threat and by $17 \%$ as a minor threat. As long as people in the EU see human rights as an important issue, it is questionable if climate change policies can translate into soft power as soft power can be "undercut by policies that are seen as illegitimate" (Nye, 2008, p. 96). 


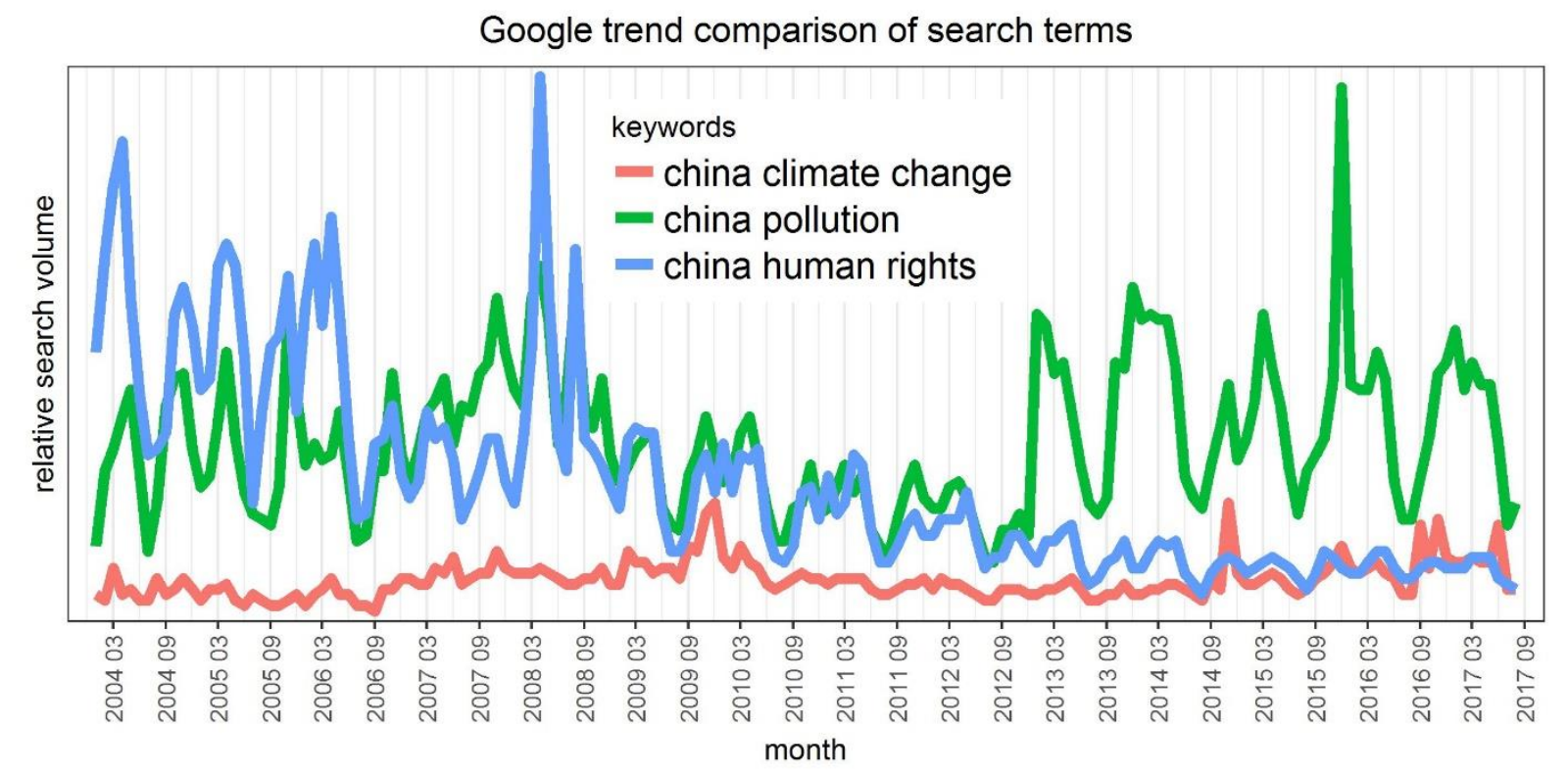

Fig. 4: Google-trends relative monthly search volume of different key words.

Third, of course, China needs to realize its own, domestic climate change politics and to adhere to its international obligations for greenhouse gas emissions in order to use climate change politics to boost its soft power. First indicators are positive in this respect, with the growth of Chinese emissions slowing (Climate Action Tracker, 2017; Ross \& Song, 2017), but a sustainable change in Chinese energy production and consumption is needed, along with a clear documentation of emissions levels and their developments in accord with the Paris agreement.

The problem of air pollution and climate change are two different problems with different solutions. In some instances, air pollution even mitigates global warming (Fiore et al., 2012). In other words, the air pollution problem can be solved without solving the climate change problem. However, if China reduces its coal consumption, both problems can be tackled at the same time. On the one hand, coal combustion in China is a major contributor to the volume of carbon dioxide emissions and thus a source of global warming (Carrington, 2016). On the other hand, "coal combustion contributes 22.5 $\mu \mathrm{gm}-3(40 \%)$ of the total PM2.5 [fine particles] concentration on national average" (Ma et al., 2017, p. 4488). Therefore, if China reduces the coal consumption most likely the local air quality will be improved, and at the same time, China reaches its goal to fight climate change. Currently, China has already achieved one of his four goals toward its 2020 climate goals and achieved up to $97 \%$ of "its carbon intensity reduction goal" (Ross \& Song, 2017). This is a strong indicator that China is willing to fulfil its international obligations.

Replacing the energy won through coal combustion forces China to make a path decision. On the one hand, China can invest in renewable energy sources and at the same time reduce carbon dioxide emissions. On the other hand, China can replace coal energy with, e.g., synthetic natural gas. This approach solves the pollution problem but does not substantially decrease greenhouse gas emissions. Only the former solution will also potentially increase soft power. China has already become the largest producer and investor in renewable energy globally (Simon-Lewis, 2017).

All things considered, China has had difficulties to gain and extend its soft power, and it has mainly relied on hard power in international relations in the form of force or money. But as Chinese leaders, as well as the Chinese public, become more aware of global 
warming and environmental issues in general, this can be helpful in the current situation. During the Obama Presidency, the United States has positioned itself at the forefront of the fight against global warming. Promoting these pro-environment and pro-economic innovation values helped the U.S. to gain soft power. With Trump and climate change deniers like Scott Pruitt in leading positions, this source of U.S. soft power could erode substantially in the near future. China has reacted swiftly after the election and presents itself as the future climate leader. Still, this move might be not enough to outdo the US overall, but it is the first step for China towards real soft power with global influence.

The future will show if China will follow up its words with actions. At least for the next four years, China has the incentives and opportunities to do so. It is an economic opportunity, it will strengthen the domestic legitimacy of the CCP, and it will eventually help China to gain soft power. China's climate change ambitions as a pivot to soft power contrast sharply with the prospective policy of the Trump administration. There is a bizarre and bitter irony in this. Donald Trump has become President of the United States with the promise to "Make America Great Again". Yet he seems completely oblivious to how much of American greatness is due to soft power.

We think that more scientific analyses of the role of climate change politics for different countries' soft power, and of the Chinese case in particular, would be warranted. Focusing on this nexus, scholars from fields like international relations could further expand the notion of soft power towards the field of environmental politics (e.g., Zeitoun, Mirumachi, \& Warner, 2011). It would also be worthwhile for interdisciplinary fields like China studies and environmental studies, which could be further integrated (e.g., Yang \& Calhoun, 2016). Studies of media communication could also benefit from focusing more on soft power, in the Chinese context and beyond, as the concept rests on a country's perception by others which are often mediated nowadays.

\section{References}

Blanchard, J.-M. F., \& Lu, F. (2012). Thinking Hard About Soft Power: A Review and Critique of the Literature on China and Soft Power. Asian Perspective, 36(4), 565589. doi:10.5555/0258-9184-36.4.565

Blas, J. \& Shankleman, J. (2017). Davos Elite Focus on Climate Change, Ignoring Trump's Skepticism. Retrieved from https://www.bloomberg.com/news/articles/201701-15/ignoring-trump-s-skepticism-davos-elite-bets-on-climate-change

Broadbent, J., Sonnett, J., Botetzagias, I., Carson, M., Carvalho, A., Chien, Y.-J., . . . Zhengyi, S. (2016). Conflicting Climate Change Frames in a Global Field of Media Discourse. Socius: Sociological Research for a Dynamic World, 2(6), 237802311667066. doi:10.1177/2378023116670660

Brownell, S. (2012). Human rights and the Beijing Olympics: imagined global community and the transnational public sphere. The British journal of sociology, 63(2), 306-327. doi:10.1111/j.1468-4446.2012.01411.x

Brunnengräber, A. (2012). Die neue Klima-Geopolitik. Forschungsjournal Soziale Bewegungen, 25(2). doi:10.1515/fjsb-2012-0204

Buchholz, L. (2013). The Global Rules of Art. (Dissertation). Columbia University, New York.

CarbonBrief. (2015). Carbon Brief's 15 numbers for 2015. Retrieved from https://www.carbonbrief.org/carbon-briefs-15-numbers-for-2015

Carrington, D. (2016). China's coal peak hailed as turning point in climate change battle. Retrieved from https://www.theguardian.com/environment/2016/jul/25/china-coalpeak-hailed-turning-point-climate-change-battle 
Climate Action Tracker. (2017). China. Retrieved from http://climateactiontracker.org/countries/china.html

Cornelissen, S. (2010). The Geopolitics of Global Aspiration: Sport Mega-events and Emerging Powers. The International Journal of the History of Sport, 27(16-18), 30083025. doi:10.1080/09523367.2010.508306

Creemers, R. (2015). Never the twain shall meet? Rethinking China's public diplomacy policy. Chinese Journal of Communication, 8(3), 306-322. doi:10.1080/17544750.2015.1046187

Daly, M., Gifford, L., Luedecke, G., McAllister, L., Nacu-Schmidt, A., Andrews, K., \& Boykoff, M. (2017). World Newspaper Coverage of Climate Change or Global Warming, 2004-2017.

DARA, Climate Vulnerable Forum. (2012). Climate Vulnerability Monitor: A Guide to the Cold Calculus of a Hot Planet. DARA and the Climate Vulnerable Forum.

Retrieved from http://daraint.org/climate-vulnerability-monitor/climate-vulnerabilitymonitor-2012/

Davenport, C. \& Lipton, E. (2016). Trump Picks Scott Pruitt, Climate Change Denialsit, to Lead E.P.A. Retrieved from https://www.nytimes.com/2016/12/07/us/politics/scottpruitt-epa-trump.html

Dietz, T., Dolšak, N., Ostrom, E., \& Stern, P. (2010). The Drama of the Commons. In E. Ostrom, T. Dietz, N. Dolšak, P. C. Stern, S. Stonich, \& E. U. Weber (Eds.), The drama of the commons (2nd ed., pp. 3-35). Washington, DC: National Academy Press.

Ding, S. (2010). Analyzing Rising Power from the Perspective of Soft Power: a new look at China's rise to the status quo power. Journal of Contemporary China, 19(64), 255272. doi:10.1080/10670560903444207

Ding, S. (2012). Is Human Rights the Achilles' Heel of Chinese Soft Power? A New Perspective on Its Appeal. Asian Perspective, 36(4), 641-665. doi:10.5555/02589184-36.4.641

Ding, S., \& Saunders, R. A. (2006). Talking up China: An analysis of China's rising cultural power and global promotion of the Chinese language. East Asia, 23(2), 3-33. doi:10.1007/s12140-006-0021-2

Dryzek, J. S., Norgaard, R. B., \& Schlosberg, D. (2011). The Oxford Handbook of Climate Change and Society. London: Oxford University Press.

The Economist Intelligence Unit. (2017). Democracy Index 2016. Revenge of the "deplorables". Retrieved from http://felipesahagun.es/wpcontent/uploads/2017/01/Democracy-Index-2016.pdf

Economy, E. C., \& Segal, A. (2008). China's Olympic Nightmare: What the Games Mean for Beijing's Future. Foreign Affairs, 84(4), 47-56.

Edney, K. (2012). Soft Power and the Chinese Propaganda System. Journal of Contemporary China, 21(78), 899-914. doi:10.1080/10670564.2012.701031

The Federal Council. (2017). China's Head of State XI Jinping to make state visit next week. Retrieved from https://www.admin.ch/gov/en/start/documentation/mediareleases.msg-id-65164.html

Fiore, A. M., Naik, V., Spracklen, D. V., Steiner, A., Unger, N., Prather, M., . . Zeng, G. (2012). Global air quality and climate. Chemical Society reviews, 41(19), 6663-6683. doi:10.1039/C2CS35095E

Freedom House. (2017). Freedom in the World 2017. Retrieved from https://freedomhouse.org/sites/default/files/FH_FIW_2017_Report_Final.pdf 
Gill, B., \& Huang, Y. (2006). Sources and limits of Chinese 'soft power'. Survival, 48(2), 17-36. doi:10.1080/00396330600765377

Grennfieldboyce, N. (2017). Trump's Budget Slashes Climate Change Funding. Retrieved from http://www.npr.org/sections/thetwo-way/2017/03/16/520399205/trumps-budgetslashes-climate-change-funding

Gries, P. H., Crowson, H. M., \& Sandel, T. (2010). The Olympic Effect on American Attitudes towards China: beyond personality, ideology, and media exposure. Journal of Contemporary China, 19(64), 213-231. doi:10.1080/10670560903444181

The Guardian. (2016). Trump seeking quickest way to quit Paris climate agreement, says report. Retrieved from https://www.theguardian.com/us-news/2016/nov/13/trumplooking-at-quickest-way-to-quit-paris-climate-agreement-says-report

Guo, X. (2010). 西方媒体对中国的环境形象建构一以 《纽约时报》全球气候变化 风险报道为例. 新闻与传播研究, (4), 18-30.

Gupta, J. (2010). A history of international climate change policy. Wiley Interdisciplinary Reviews: Climate Change, 1(5), 636-653. doi:10.1002/wcc.67

Harrison, K., \& Sundstrom, L. M. (2007). The Comparative Politics of Climate Change. Global Environmental Politics, 7(4), 1-18. doi:10.1162/glep.2007.7.4.1

Hartig, F. (2012). Confucius Institutes and the Rise of China. Journal of Chinese Political Science, 17(1), 53-76. doi:10.1007/s11366-011-9178-7

Heng, Y.-K. (2010). Mirror, mirror on the wall, who is the softest of them all? Evaluating Japanese and Chinese strategies in the 'soft' power competition era. International Relations of the Asia-Pacific, 10(2), 275-304. doi:10.1093/irap/lcp023

Hilton, I. (2016). China emerges as global climate leader in wake of Trump's triumph. Retrieved from https://www.theguardian.com/environment/2016/nov/22/donaldtrump-success-helps-china-emerge-as-global-climate-leader

Holland, S. \& Volcovici, V. (2017). Trump clears way for controversial oil pipelines. Retrieved from http://www.reuters.com/article/us-usa-trump-pipelineidUSKBN15820N

Hooghe, I. d. (2010). The limits of China's soft power in Europe: Beijing's public diplomacy puzzle. Clingendael diplomacy papers: no. 25. The Hague: Netherlands Institute of International Relations "Clingendael".

Hu, A., Zhang, J., \& Gao, Y. (2017). 对外援助与国家软实力: 中国的现状与对策. 武 汉大学学报 (人文科学版)，70(3), 5-13.

Hunter, A. (2009). Soft Power: China on the Global Stage. The Chinese Journal of International Politics, 2(3), 373-398. doi:10.1093/cjip/pop001

IPCC. (2014). Fifth Assessment Report. Geneva.

Johannessen, J. (2015). Worldview Struggles under a New Climate Regime. Nordicom Review, 36(1). doi:10.1515/nor-2015-0004

Keohane, R. O., \& Victor, D. G. (2011). The Regime Complex for Climate Change. Perspectives on Politics, 9(01), 7-23. doi:10.1017/S1537592710004068

Konieczny, E. (2014). Gipfel, Krisen, Konferenzen. Die Entstehung Diskursiver Macht in transnationalen Kommunikationsereignissen. Wiesbaden, Germany: Springer.

Lanteigne, M. (2012). Water dragon? China, power shifts and soft balancing in the South Pacific. Political Science, 64(1), 21-38. doi:10.1177/0032318712447732

Leng, S. (2017). Dumping of untreated acid in Chinese canal highlights nation's water pollution woes. Retrieved from 
http://www.scmp.com/news/china/article/2059329/dumping-untreated-acid-chinesecanal-highlights-nations-water-pollution

Liang, X., Tsai, J.-Y., Mattis, K., Konieczna, M., \& Dunwoody, S. (2014). Exploring Attribution of Responsibility in a Cross-National Study of TV News Coverage of the 2009 United Nations Climate Change Conference in Copenhagen. Journal of Broadcasting \& Electronic Media, 58(2), 253-271. doi:10.1080/08838151.2014.906436

Ma, Q., Cai, S., Wang, S., Zhao, B., Martin, R. V., Brauer, M., . . Burnett, R. T. (2017). Impacts of coal burning on ambient $\mathrm{PM}<\mathrm{sub}>2.5</ \mathrm{sub}>$ pollution in China. Atmospheric Chemistry and Physics, 17(7), 4477-4491. doi:10.5194/acp-17-44772017

Manzenreiter, W. (2010). The Beijing Games in the Western Imagination of China: The Weak Power of Soft Power. Journal of Sport and Social Issues, 34(1), 29-48. doi: $10.1177 / 0193723509358968$

McClory. (2017). The Soft Power 30. A Global Ranking of Soft Power 2017. Retrieved from https://softpower30.com/wp-content/uploads/2017/07/The-Soft-Power-30Report-2017-Web-1.pdf

Mingjiang, L. (2008). China Debates Soft Power. The Chinese Journal of International Politics, 2(2), 287-308. doi:10.1093/cjip/pon011

Nordin, A. (2012). How Soft Is “Soft Power"? Unstable Dichotomies at Expo 2010. Asian Perspective, 36(4), 591-613. doi:10.5555/0258-9184-36.4.591

Nye, J. S. (1990a). The Changing Nature of World Power. Political Science Quarterly, 105(2), 177. doi:10.2307/2151022

Nye, J. S. (1990b). Soft Power. Foreign Policy, 80, 153-171.

Nye, J. S. (2002). The Information Revolution and American Soft Power. Asia-Pacific Review, 9(1), 60-76. doi:10.1080/13439000220141596

Nye, J. S. (2005a). The Rise of China's Soft Power. Wall Street Journal Asia. Retrieved from http://www.belfercenter.org/publication/rise-chinas-soft-power

Nye, J. S. (2005b). Soft Power and Higher Education (EDUCAUSE). Retrieved from Forum for the Future of Higher Education website: http://www.educause.edu/ir/library/pdf/ffpiu043.pdf

Nye, J. S. (2008). Public Diplomacy and Soft Power. The ANNALS of the American Academy of Political and Social Science, 616(1), 94-109. doi:10.1177/0002716207311699

Obama, B. (2017). The irreversible momentum of clean energy. Science, 355(6321), 126129. doi:10.1126/science.aam6284

Otmazgin, N. K. (2007). Contesting soft power: Japanese popular culture in East and Southeast Asia. International Relations of the Asia-Pacific, 8(1), 73-101. doi:10.1093/irap/lcm009

Painter, J. (2011). Poles apart. Oxford: Reuters Institute for the Study of Journalism.

Paradise, J. F. (2009). China and International Harmony: The Role of Confucius Institutes in Bolstering Beijing's Soft Power. Asian Survey, 49(4), 647-669. doi:10.1525/as.2009.49.4.647

Pew Research Center. (2016a). Chinese Public Sees More Powerful Role in World, Names U.S. as Top Threat. Retrieved from http://assets.pewresearch.org/wpcontent/uploads/sites/2/2016/10/Pew-Research-Center-China-Report-FINAL-October5-2016.pdf 
Pew Research Center. (2016b). Europeans Face the World Divided. Retrieved from http://assets.pewresearch.org/wp-content/uploads/sites/2/2016/06/14095145/PewResearch-Center-EPW-Report-FINAL-June-13-2016.pdf

Phillips, T. (2016). Climate change a Chinese hoax? Beijing gives Donald Trump a lesson in history. Retrieved from https://www.theguardian.com/usnews/2016/nov/17/climate-change-a-chinese-plot-beijing-gives-donald-trump-ahistory-lesson

Qin, A. \& Tatlow, D. K. (2014). What's in a Word? A Chinese Dictionary Updates. Retrieved from https://sinosphere.blogs.nytimes.com/2014/08/31/whats-in-a-word-achinese-dictionary-updates/

Ross, K. \& Song, R. (2017). China Making Progress on Climate Goals Faster than Expected. Retrieved from http://www.wri.org/blog/2017/03/china-making-progressclimate-goals-faster-expected

Ryoo, W. (2009). Globalization, or the logic of cultural hybridization: the case of the Korean wave. Asian Journal of Communication, 19(2), 137-151. doi:10.1080/01292980902826427

Schmidt, A., Ivanova, A., \& Schäfer, M. S. (2013). Media attention for climate change around the world: A comparative analysis of newspaper coverage in 27 countries. Global Environmental Change, 23(5), 1233-1248. doi:10.1016/j.gloenvcha.2013.07.020

Schmidt, A., \& Schäfer, M. S. (2015). Constructions of climate justice in German, Indian and US media. Climatic Change, 133(3), 535-549. doi:10.1007/s10584-015-1488-x

Schreurs, M. A., \& Tiberghien, Y. (2007). Multi-Level Reinforcement: Explaining European Union Leadership in Climate Change Mitigation. Global Environmental Politics, 7(4), 19-46. doi:10.1162/glep.2007.7.4.19

Segerberg, A. (2017). Online and Social Media Campaigns for Climate Change Engagement. Retrieved from http://climatescience.oxfordre.com/10.1093/acrefore/9780190228620.001.0001/acrefo re-9780190228620-e-398

Servaes, J. (2015). The Chinese dream shattered between hard and soft power? Media, Culture \& Society, 38(3), 437-449. doi:10.1177/0163443716631283

Shankleman, J. (2016). China Tells Trump That Climate Change Is No Hoax It Invented. Retrieved from https://www.bloomberg.com/news/articles/2016-11-16/china-tellstrump-that-climate-change-is-no-hoax-it-invented

Simon-Lewis, A. (2017). How China is leading the world in solar energy production. Retrieved from http://www.wired.co.uk/article/china-climate-change-policy-solarproduction

Spence, A., Poortinga, W., Butler, C., \& Pidgeon, N. F. (2011). Perceptions of climate change and willingness to save energy related to flood experience. Nature Climate Change, 1(1), 46-49. doi:10.1038/NCLIMATE1059

Thomas, D. C. (2001). The Helsinki effect: International norms, human rights, and the demise of communism. Princeton, NJ: Princeton Univ. Press. Retrieved from http://www.loc.gov/catdir/description/prin022/2001016375.html

Wang, H., \& Lu, Y.-C. (2008). The Conception of Soft Power and its Policy Implications: a comparative study of China and Taiwan. Journal of Contemporary China, 17(56), 425-447. doi:10.1080/10670560802000191 
Wang, Y. (2008). Public Diplomacy and the Rise of Chinese Soft Power. The ANNALS of the American Academy of Political and Social Science, 616(1), 257-273. doi:10.1177/0002716207312757

World Economic Forum. (2017). The Global Risks Report 2017. 12th Edition. Retrieved from http://www3.weforum.org/docs/GRR17_Report_web.pdf

Wu, Z., \& Taylor, I. (2011). From refusal to engagement: Chinese contributions to peacekeeping in Africa. Journal of Contemporary African Studies, 29(2), 137-154. doi:10.1080/02589001.2011.555190

Xi, J. (2008). 关于中国特色社会主义理论体系的几点学习体会和认识 (2). Retrieved from http://theory.people.com.cn/GB/41038/7069571.html

Xi, J. (2012). 全面贯彻落实党的十八大精神要突出抓好六个方面工作. Retrieved from http://www.qstheory.cn/zxdk/2013/201301/201212/t20121227_202448.htm

$\mathrm{Xu}, \mathrm{P}$. (2010). China: Emerging player with a historical legacy. In E. Eide \& R. Kunelius (Eds.), Global climate, local journalism: A transnational study of how media make sense of climate summits (pp. 131-145). Bochum, Germany: ProjektVerlag.

Yahuda, M. (2013). China's New Assertiveness in the South China Sea. Journal of Contemporary China, 22(81), 446-459. doi:10.1080/10670564.2012.748964

Yang, G. (2015). The affective publics of under the dome. Retrieved from https://mediaactivism.org/2015/04/12/the-affective-publics-of-under-the-dome/

Yang, G., \& Calhoun, C. (2016). Media, Civil Society, and the Rise of a Green Public Sphere in China. China Information, 21(2), 211-236. doi:10.1177/0920203x07079644

Zeitoun, M., Mirumachi, N., \& Warner, J. (2011). Transboundary water interaction II: the influence of 'soft' power. International Environmental Agreements: Politics, Law and Economics, 11(2), 159-178. doi:10.1007/s10784-010-9134-6 